Iwona Imańska Instytut Informacii Naukowej i Bibliologii Uniwersytet Mikołaja Kopernika w Toruniu e-mail: iwim@umk.pl

\title{
Biblioteka Jakuba Bliwernitza (1667-1731), burmistrza Malborka
}

DOI: $10.12775 /$ TSB.2013.019

STRESZCZEnIE: Żyjący na przełomie wieków XVII i XVIII Jakub Bliwernitz należał do grona dobrze wykształconej elity Malborka. Kilkakrotnie był burmistrzem miasta. Studiował prawo i interesował się historią regionu. Dał się poznać także jako właściciel sporego, bo liczącego około 2 tysięcy tytułów, księgozbioru. Po jego śmierci biblioteka została sprzedana na publicznej aukcji, zorganizowanej w Malborku od 16 lipca 1732 r. Wydrukowany na tę okazję katalog aukcyjny umożliwia zapoznanie się z zawartością biblioteki, która charakterem zbiorów i wielkością nie odbiegała od bibliotek prywatnych gromadzonych w tym samym czasie przez urzędników miejskich większych miast prowincji, takich jak Toruń i Elbląg. W bibliotece Bliwernitza dominowały książki z zakresu prawa i polityki oraz historii, uzupełnione o literaturę religijną, książki z czasów szkolnych i podstawowe dzieła z innych dziedzin wiedzy. Księgozbiór służył burmistrzowi przede wszystkim w wykonywaniu jego obowiązków zawodowych i realizowaniu zainteresowań historycznych.

SŁowA KLUCzowe: biblioteki prywatne, Bliwernitz Jakub (1667-1731), księgozbiory historyczne, Malbork, XVII-XVIII w.

\section{Wprowadzenie}

$\mathrm{O}$ d XVI w. w Prusach Królewskich istniały dogodne warunki do kompletowania prywatnych księgozbiorów. Ich właścicielami byli przede 
wszystkim zamożni i dobrze wykształceni przedstawiciele patrycjatu dużych miast prowincji, Gdańska, Torunia i Elbląga. Biblioteki powstawały jako przejaw pasji kolekcjonerskiej tej warstwy społeczności, ale coraz częściej posiadanie księgozbiorów związane było z wykonywaną pracą: książki były niezbędnym elementem w pracy uczonych, profesorów, lekarzy, duchownych, urzędników wyższych szczebli. Z czasem duża część tych bibliotek przekształciła się w kolekcje kilkutysięczne, bogate w dzieła mówiące o interesowaniu się miejscowych elit nowinkami w nauce i kulturze europejskiej. Dbałość o nie przejawiała się w zaopatrywaniu nabytych książek we wspaniałe oprawy, w podkreślaniu przynależności poprzez ekslibrisy, rzadziej superekslibrisy. Stopniowo grono czytelników się powiększało i książka, głównie użytkowa i religijna, docierała do niższych warstw społecznych.

W mniejszej skali biblioteki prywatne znajdujemy w domach mieszczan zamieszkałych miasta średniej wielkości. Jednym z nich był Malbork, w którym na początku XVIII stulecia mieszkało około cztery tysiące osób ${ }^{1}$. Władza w mieście spoczywała w rękach protestantów, głównie wyznania luterańskiego, którzy stosowali politykę ograniczającą dopuszczanie do prawa miejskiego i cechów katolików, a także protestantów innych wyznań, w tym kalwinów i menonitów. W rękach luteran było także szkolnictwo, gdyż utrzymywali oni szkołę średnią, obok której działało jeszcze powstałe w 1680 r. pięcioklasowe kolegium jezuickie ${ }^{2}$.

Ze względu na wielkość i pozycję miasta, Malbork od takich ośrodków, jak pobliski Gdańsk, czy nawet Elbląg i Toruń różniły się nie tylko liczbą mieszkańców, ale także ich strukturą zawodową. Jednym z tego przejawów było mniejsze zapotrzebowanie na osoby z wykształceniem akademickim ${ }^{3}$. Tym, którzy wracali po skończeniu studiów w rodzinne strony miasto oferowało gorsze warunki finansowe, dlatego bardziej ambitni z czasem szukali zatrudnienia w sąsiednich ośrodkach.

Z tych powodów można się spodziewać, że w domach mieszkańców znajdowało się mniej prywatnych bibliotek. 0 kolekcjonerstwie książek

1 K. Górski, Dzieje Malborka, Gdynia 1960, s. 163.

2 Tamże, s. 167; E. Cieślak, Kultura i ideologia w życiu Prus Królewskich, [w:] Historia Pomorza, t. 2: Do roku 1815, cz. 2 (Pomorze Wschodnie w l. 1657-1815), pod red. G. Labudy, Poznań 1984, s. 280.

${ }^{3}$ M. Pawlak, W. Długokęcki, Studia uniwersyteckie malborczyków do 1773 roku, Bydgoszcz 2004, s. 24, 26. 
wśród malborczyków wiemy dotąd bardzo niewiele. Najwięcej wzmianek dotyczy księgozbiorów gromadzonych od drugiej połowy XVII stulecia. Wiemy, że trzy z zapoczątkowanych w tym czasie kolekcji w pierwszych dziesięcioleciach następnego wieku zostały po śmierci ich właścicieli wystawione na publiczną sprzedaż. Należały do przedstawicieli władzy w Malborku. Pierwsza była własnością bliżej nieokreślonego Kafemanna lub rodziny Kafemannów, której członkowie na początku XVIII w. pełnili różne funkcje we władzach miejskich, na przykład Krzysztof Kafemann od 1705 r. był sekretarzem, a następnie ławnikiem miejskim ${ }^{4}$. Liczący 1320 woluminów księgozbiór został zlicytowany w Malborku 3 października 1718 r., a na miejsce aukcji wybrano dom Jerzego Treuge, wówczas rektora luterańskiej szkoły średniej ${ }^{5}$. Była to pierwsza znana nam licytacja książek przeprowadzona w Malborku. W wyprzedawanym zbiorze przewagę miała literatura historyczna i książki z zakresu prawa, wśród których znajdowało się sporo prac poświęconych dziejom prowincji ${ }^{6}$. Podobnie postąpiono z dwoma księgozbiorami prywatnymi na początku lat 30. XVIII w.: rajcy Henryka Benigkena i burmistrza Jakuba Bliwernitza. Aukcja pierwszego przeprowadzona została w Toruniu od 25 czerwca 1732 r. Oferowano na niej trochę ponad 850 woluminów wydanych przeważnie w XVII stuleciu. Benigken był właścicielem jednego inkunabułu, kilku rękopisów oraz wielu ciekawych wydawnictw ilustrowanych i druków pochodzących z uznanych europejskich tłoczni, w tym publikacji holenderskiej firmy Elzewir i działającego w Antwerpii Krzysztofa Plantina. Pod względem treści dominowały książki z zakresu prawa, polityki i historii ${ }^{7} 0$ księgozbiorze Bliwernitza do niedawna nie-

${ }^{4}$ Por. Archiwum Państwowe w Gdańsku, sygn. 4/4 s. 309-312; sygn. 508/1885: jest to księga protokołów Rady miasta Malborka z 1718 r. za okres od 3 do 20 stycznia, spisanych przez Krzysztofa Kafemanna.

${ }^{5}$ A. Pusch. Marienburgscher evengelischer Lehrer Gedächtniss, die seit der Reformation an der St. Georg-Kirchen gelehret, Danzig 1753, s. 58.

${ }^{6}$ Catalogus bibliothecae Kafemannianae auctione publica, parata pro pecunia distrahendae Mariaeburgi, in aedibus fmti Georgi Treuge d. mensis Septembr. [przekreślone i dopisane atram. 3. Octobr.] Anno Dni. 1718, Gedani [1718] (egzemplarz katalogu w zbiorach Biblioteki Narodowej w Warszawie, sygn. XVIII.2.4643).

7 Catalogus librorum viri quondam amplissimi consultissimi dn. Henrici Benigken, consul. civil. Mariaeburg. qui jam auctionis lege venales proscripti, pro argento praesenti divendentur hic loci d. 25. sqq. Mens. Junii Anno 1732. in aedibus Gottsteinianis, Thorunii [1732] (egzemplarz katalogu znajduje się w zbiorach Wojewódzkiej Biblioteki Publicznej 
wiele było wiadomo, prócz przypuszczenia, że mógł posiadać ciekawy zbiór, czego dowodem były pojedyncze egzemplarze z jego podpisem na kartach tytułowych, na które natrafiono w kilku bibliotekach ${ }^{8}$. Okazało się jednak, że jego kolekcja również została sprzedana na aukcji, półtora miesiąca po licytacji zbiorów Benigkena, mianowicie 16 lipca 1732 r., ale tym razem licytacja odbyła się w Malborku, w domu wdowy, a dowodem na jej przeprowadzenie jest katalog aukcyjny przechowywany obecnie w zbiorach Archiwum Państwowego w Toruniu9.

\section{Właściciel księgozbiorv}

Jakub Bliwernitz (1667-1731) urodził się w Toruniu. Był synem rajcy Jakuba i Urszuli Thoratin, córki chirurga Krzysztofa. Spokrewniony był ze znanym pastorem toruńskim Aaronem Bliwernitzem, który służył w kościołach św. Jerzego i Najświętszej Marii Panny. Otrzymał staranne wykształcenie, ucząc się od 1681 r. w Gimnazjum Akademickim w Elblągu, w lipcu 1683 r. został wpisany do supremy w toruńskim gimnazjum akademickim, a w następnym roku, z rekomendacją historyka i profesora szkoły toruńskiej Krzysztofa Hartknocha, udał się do Królewca, gdzie studiował prawo ${ }^{10}$. Po powrocie do Malborka rozpoczął karierę urzędniczą, będąc kolejno: sekretarzem Rady miejskiej, członkiem Ławy i rajcą, by w 1701 r. po raz pierwszy zostać prezydującym burmistrzem.

- Książnicy Kopernikańskiej w Toruniu (dalej: WBP - Książnica Kopernikańska), sygn. A-365(3).

${ }^{8}$ Książki z biblioteki Bliwernitza znajdują się między innymi w Bibliotece Gdańskiej PAN i WBP -Książnicy Kopernikańskiej w Toruniu.

9 Na katalog natrafiono, porządkując część zbiorów Archiwum, tzw. akta luźne, spośród których spora partia to dokumenty do dziejów księgozbiorów i drukarstwa toruńskiego i pruskiego. Por. K. Kopiński, Katalog rękopisów do dziejów księgozbiorów i drukarstwa toruńskiego i pruskiego w zespole archiwalnym Akta miasta Torunia z okresu staropolskiego, „Folia Toruniensia” 5: 2005, s. 97.

10 H. Strehlau, Jacob Bliwernitz (1666-1731), Bürgermeister zu Marienburg in Westpreußen, „Ostdeutsche Familienkunde” 9: 1961, H. 1, s. 300-301; Die Matrikel des Gymnasiums zu Elbing (1598-1786), Hrsg. von H. Abs, Hamburg 1982, s. 167; Metryka uczniów Toruńskiego Gimnazjum Akademickiego 1600-1817, cz. 1 (1600-1717), wyd. Z. H. Nowak, J. Tandecki, Toruń 1997, s. 209; Die Matrikel und die Promotionsverzeichnisse der Albertus-Universität zu Königsberg in Preussen 1544-1829, Bd. 2, Hrsg. von G. Erler, Leipzig 1911-1912, s. 139. 
Stanowisko to sprawował siedmiokrotnie, w tym w trudnych dla miasta czasach wojny północnej. Ożenił się z Marią Dorotą Erdmann ${ }^{11}$.

Bliwernitz interesował się również historią, przede wszystkim dziejami miasta i regionu, czego owocem były teksty zamieszczane na łamach „Erleutertes Preussen”, czasopisma wydawanego w Królewcu przez Michaela Lilienthala. W pierwszym jego tomie znalazły się dwa artykuły autorstwa Bliwernitza: pierwszy dotyczył historii Malborka i był uzupełnieniem informacji o tym mieście podanych przez jego byłego profesora z gimnazjum toruńskiego, K. Hartknocha w dziele Alt und Neues Preussen oder Preussischer Historien (Frankfurt i Lipsk 1684), drugi poświęcony został pieczęciom pruskim ${ }^{12}$.

Jako osoba dobrze wykształcona, wysoki urzędnik miejski łączący to stanowisko z pasją historyczną, Bliwernitz nie mógł obejść się bez księgozbioru, dziś, jak wspomniano, znanego dzięki zachowanemu katalogowi aukcyjnemu. Jest to broszurka formatu czwórki o objętości 67 stron, której druk powierzono gdańskiej oficynie należącej do Tomasza Jana Schreibera ${ }^{13}$. Od strony edytorskiej wydrukowany przez Schreibera katalog nie odbiegał od innych katalogów aukcyjnych publikowanych wówczas w Gdańsku. Pozbawiony był wszelkich elementów ozdobnych, jedynie na stronie kończącej spis drukarz umieścił drzeworytowy ornament geometryczny. Wystawione na publiczną sprzedaż książki również zostały spisane w porządku najczęściej wówczas stosowanym, czyli według formatów, od największego, in folio, poczynając, a na in duodecimo kończąc. Najpierw umieszczono książki oprawne, po nich Libri incompacti et in cruda materia, a następnie od strony 45 Appendix, w którym na końcu również wydzielono Crudae materiae. Całość kończy 13 pozycji

11 H. Strehlau, dz. cyt., s. 301; A. Groth, Bliwernitz Jakub, [w:] Słownik biograficzny Pomorza Nadwiślańskiego, supl. 2, pod red. Z. Nowaka, Gdańsk 2002, s. 38.

12 K. Estreicher, Bibliografia polska, t. XIII, Kraków 1894, s. 168; J. Bliwernitz, Anmerckungen über seel. M. Hartknochs Beschreibung der Stadt Marienburg im A. und N. Preussen, p. 405, „Erleutertes Preussen” 1: 1723, St. 9, s. 704-721; tenże, Von denen Land-und Hohemeisterlichen Siegeln in Preussen, tamże, 1: 1723, St. 11, s. 824-835.

13 Catalogus librorum juridicorum, theologicorum, maximam vero partem Historicorum selectiorum, Viri B.M. Pre-Nobilissimi, Amplissimi et Consultissimi Domini, Domini Jac. Bliwernitz, Prae-Consulis Mariaeburgensis Meritissimi, in aedibus viduae pié defuncti, Horis et legibus consvetis auctione publica distrahendorum, Mariaeburgi Anno 1732. [rz.] d. 16. Julii [data dzienna dopisana atram.], Gdańsk [1732] (egzemplarz katalogu znajduje się w zbiorach Archiwum Państwowego w Toruniu, sygn. Kat. II, XIV-15, k. 130-164). 


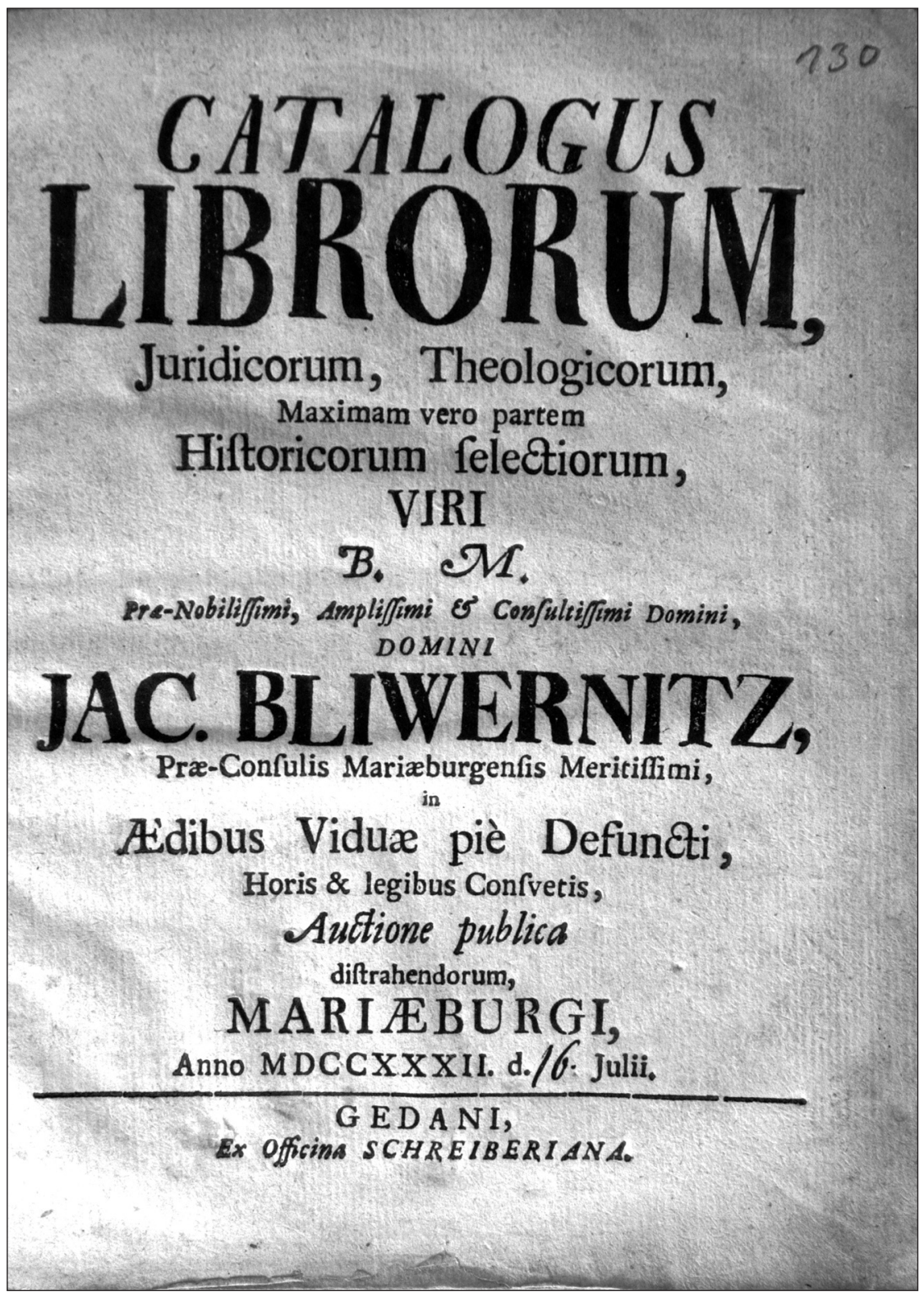

Ilustracja 1. Karta tytułowa katalogu aukcyjnego rejestrującego bibliotekę J. Bliwernitza

Źródło: zbiory Archiwum Państwowego w Toruniu, sygn. Kat. II, XIV,15, s. 130. 
określonych jako Mathematische und astronomische Sachen. W głównej części katalogu wykazanych zostało 960 woluminów oprawnych i 72 bez opraw, Dodatek zawiera 558 woluminów zaopatrzonych w oprawy oraz 19 w postaci crudae materiae. Tytułów jest trochę więcej, gdyż przyjętym zwyczajem w katalogach aukcyjnych numerowane były woluminy, a nie tytuły, czyli dzieło na przykład trzytomowe to pozycje od jeden do trzy, a z kolei tom zawierający pod wspólną oprawą kilka drobnych druków stanowi według tego systemu jedną pozycję w katalogu. Z reguły zawartość takiego klocka introligatorskiego była rozpisywana. Jest jednak kilkanaście woluminów o zbiorczym tytule np. Fasciculus Dispp. Juridicarum, Ein Pack Leichen Predigten, Ein Pack Dantz. Lateinisch Oration itp. W sumie katalog wykazuje 1609 pozycji, a biorąc pod uwagę dzieła wielotomowe i zawartość rozpisanych klocków introligatorskich tytułów jest nie mniej niż 1900.

Książki spisane w części określonej jako Appendix to jedna trzecia tego zbioru, więc stosunkowo dużo, dlatego istniała możliwość, że była to partia dzieł nienależących do burmistrza, być może fragment jakiejś innej kolekcji, którą chciano sprzedać, korzystając z tej sposobności. Treściowo jednak ta część oferty aukcyjnej nie odbiegała od podstawowego zbioru. Poza tym jedna z książek umieszczonych w Dodatku dziś przechowywana jest w zbiorach starych druków Książnicy Kopernikańskiej w Toruniu. O tym, że była własnością burmistrza, świadczy pozostawiony przez niego podpis na karcie tytułowej. Są to wydane w Braniewie w 1616 r. Privilegia der Stände dess Hertzogthumbs Preussen ${ }^{14}$. Jest to też dowód na to, że torunianie brali udział w aukcji biblioteki Bliwernitza. Być może do Malborka wybrał się młody wówczas, 17-letni Efraim Oloff, syn pastora noszącego takie samo imię, ponieważ w 1768 r. właśnie z licytacji jego księgozbioru Privilegia trafiły do biblioteki gimnazjum toruńskiego. Aukcja malborska zainteresowała także środowisko kolekcjonerów gdańskich, w tym opiekunów książnicy Senatu Gdańskiego, do zbiorów której zakupiono z biblioteki Bliwernitza osiem woluminów ${ }^{15}$. Dwa z nich w katalogu mieszczą się w Dodatku. Wszystkie nabytki możemy dziś

14 Egzemplarz w zbiorach WBP - Książnicy Kopernikańskiej o sygn. 112075.

15 Index Librorum qui ex donatione, munificentia et liberalitate philomusorum Bibliothecae Magnifici et Amplissimi Senatus Gedanensis inserti sunt, rękopis w zbiorach Biblioteki Gdańskiej PAN, sygn. Cat. Bibl. 1, s. 627. 
określić wspólnym mianem polonika. Były to prace z zakresu historii polskiej i pruskiej, w tym też dzieła publikowane w gdańskich oficynach w poprzednich stuleciach ${ }^{16}$.

\section{Księgozbiór Bliwernitza}

Przechodząc do charakterystyki księgozbioru malborskiego burmistrza, trzeba zaznaczyć, że nie mamy pewności, czy na licytację przeznaczone zostały wszystkie książki przez niego zgromadzone. Biorąc jednak pod uwagę wielkość licytowanej kolekcji, nieodbiegającej od bibliotek prywatnych urzędników miejskich żyjących w tym czasie w większych miastach, takich jak Toruń czy nawet Gdańsk, wydaje się, że jeżeli nie jest to cały zbiór Bliwernitza, to na pewno jego zdecydowana część.

Katalog aukcyjny niestety nie daje nam możliwości wnioskowania o podejściu ich właściciela do książek. W opisach bibliograficznych w zasadzie pominięto informacje o rodzaju opraw, w jakie były zaopatrzone nabywane dzieła. Wiemy jedynie, że zdecydowana większość je posiadała, a pięć miało oprawy określone jako francuskie. Cztery książki, w tym trzy z zakresu prawa, to egzemplarze interfoliowane, charakteryzujące się tym, że pomiędzy kartami zadrukowanymi miały wszyte czyste karty, na których można było robić notatki. Nie ma podstaw, aby sądzić, że Bliwernitz interesował się szczególnie publikacjami rzadkimi, efektownymi od strony edytorskiej czy bogato zdobionymi. Zaledwie przy trochę ponad 40 pozycjach zaznaczone zostało, że charakteryzują się ilustracjami, przede wszystkim miedziorytowymi. Wydaje się raczej, że o włączeniu książki do biblioteki w jego przypadku decydował element użytkowy, a nie podejście bibliofilskie. Malborczyk nie postarał się o ekslibris, a o jego związku z książką mówił podpis, który umieszczał na kartach tytułowych.

${ }^{16}$ Były to: K. Hartknoch, Preussische Kirchen-Historia, Frankfurt n. Menem, Lipsk 1686; K. Zawadzki, Historia arcana, seu annalium polonicorum libri VII, [Frankfurt] 1699; J. Sobieski, Commentarium Chotinensis belli libri tres, Gdańsk 1646; W. Kojałowicz, Historiae Lituanae, Gdańsk 1650; B. Zawadzki, Infula Cracoviensis gemmis suis distincta seu antistitum Cracoviensium ab ipsis cathedrae propriae, Warszawa 1686; J. Leo, Historia Prussiae, Braniewo 1725; P. Vogel, Wahrhafftiger und gründlicher Bericht von Belager und Eroberung der Haupt-Schantze in der Dantziger Nährung... von den Schweden anno MDCLVI, Gdańsk 1661; Gründliche Erklaerung aus was Ursachen die Ordnungen der Statt Dantzigk 


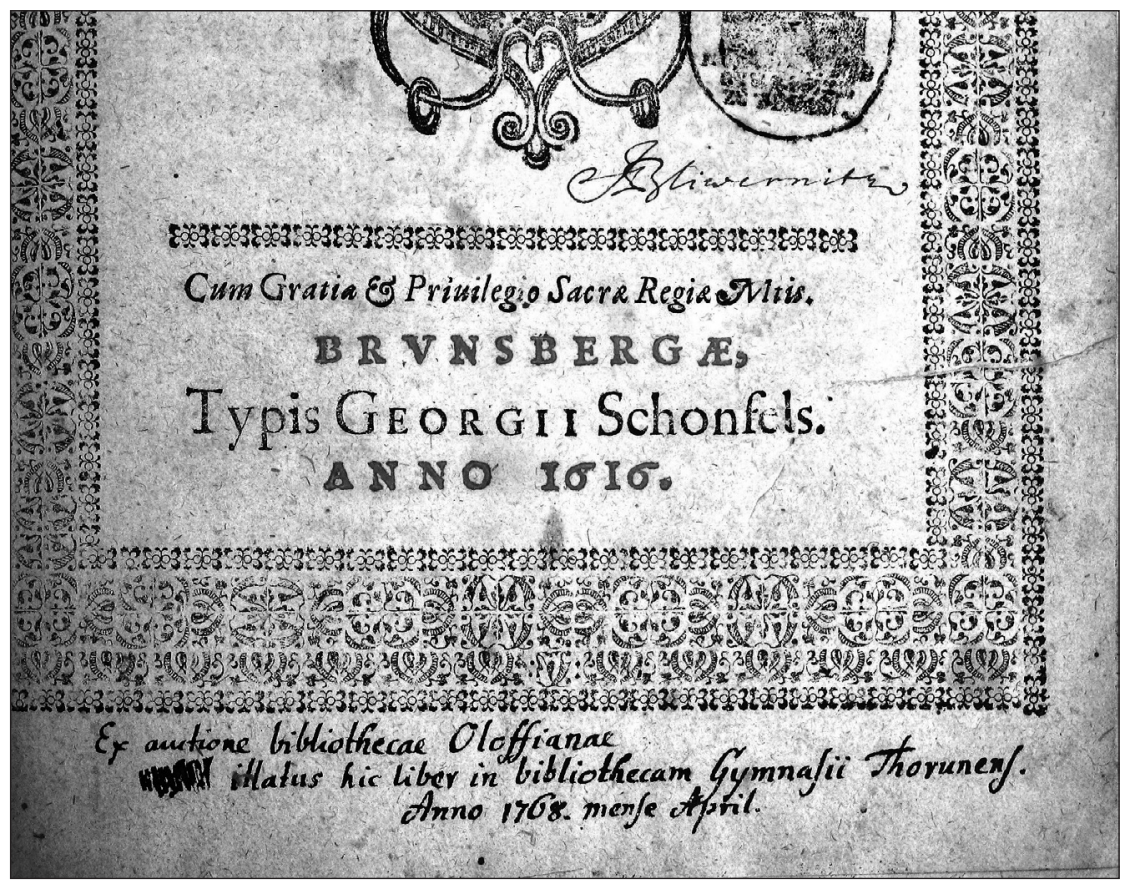

Ilustracja 2. Podpis J. Bliwernitza na karcie tytułowej książki Privilegia der Stände dess Herzogthumbs Preussen, Braniewo 1616

Źródło: zbiory Wojewódzkiej Biblioteki Publicznej - Książnicy Kopernikańskiej w Toruniu, sygn. 112075.

W omawianej bibliotece dominowały książki drukowane i choć nie wyodrębniono osobnego działu na rękopisy, to wśród druków wymienionych było prawie 30 manuskryptów, głównie odnoszących się do spraw lokalnych. Prawie wszystkie zostały wykazane w części głównej katalogu wśród książek formatu folio. Bliwernitz miał np. kilka odpisów rękopiśmiennych prawa chełmińskiego, w tym jeden po łacinie, dwa w języku niemieckim, a kolejny egzemplarz z adnotacją sauber geschrieben. Były też dwa wilkierze miasta Gdańska, rękopis określony jako „Das Recht der Lande Preussen” oraz kilka związanych ze sprawami prawnymi i ekono-

mit...Stephano Könige zu Polen...in den...obstehenden Missverstandt und Weiterung geraten und eingeführet, Gdańsk 1577. 
micznymi Malborka. Prócz dokumentów z zakresu prawa były również rękopiśmienne księgi o treści historycznej, jak „Historische Beschreibung der Stadt Dantzig [1]646" Reinholda Curicke, czy zbiór dokumentów określonych jako „Compendium Historiae” Joachima Posseliusa, lekarza i nadwornego historiografa królewskiego na dworze Zygmunta III, który pozostawił w rękopisie „Historia rerum polonicarum et pruthenicarum ab a. 1389 ad a. 1623"17. Praca Curicke, główne dzieło tego autora, ukończona została w 1642 r., ale władze Gdańska sprzeciwiły się jej druku ze względu na sposób przedstawienia w niej problemów religijnych miasta. Światło dzienne ujrzała dopiero w latach 1687-1688 za sprawą syna Reinholda, Jerzego Reinholda pod tytułem Der Stadt Dantzig historische Beschreibung, z adresem wydawniczym Amsterdam i Gdańsk ${ }^{18}$. Ten przykład pokazuje, że dzieło znane było czytelnikom krótko po jego powstaniu w odpisach rękopiśmiennych. Trzeba tu jeszcze dodać, że Bliwernitz nabył też jego wersję drukowaną. Poza kwestie prawne i historyczne wychodził manuskrypt zatytułowany „Msct. von Preussl. Müntz-Wesen”.

Zgromadzona przez burmistrza literatura drukowana to w dwóch trzecich książki publikowane w XVII stuleciu, 12\% spośród dzieł, które miały podany w opisie rok wydania, wytłoczonych zostało w XVI w., a co piąta książka pochodziła z XVIII w. Tu trzeba zaznaczyć, że Bliwernitz uzupełniał kolekcję do końca życia, gdyż posiadał nawet druki opublikowane w końcu lat 20. i na początku 30. XVIII w., jak np. Historia Consensus Sandomiriensis, dzieło Daniela Ernesta Jabłońskiego drukowane w 1731 r. w Berlinie, czy kolejny tom z 1730 r. czasopisma wydawanego w Toruniu pod tytułem „Preussischer Todes-Tempel”. Przewaga dzieł z wieku XVII i stosunkowo duża partia książek wydanych w pierwszych dziesięcioleciach następnego skłania do wniosku, że głównym twórcom biblioteki był Bliwernitz.

Zgodnie z informacją zamieszczoną na karcie tytułowej, Bliwernitz miał dość szerokie zainteresowania czytelnicze, gromadził literaturę o różnorodnej treści z przewagą dzieł z zakresu prawa, polityki i historii. Ze względu na wykształcenie, sprawowane urzędy i interesowanie się

17 G. Mańk, Possel (Posselius) Joachim, [w:] Polski słownik biograficzny [dalej cyt:: PSB], t. 27/4, Wrocław 1983, s. 696.

18 P. Szafran, Warsztat historyczny Reinholda Curicke dziejopisarza Gdańska XVII wieku w świetle jego księgozbioru (Z dziejów księgozbiorów prywatnych w Gdańsku w XVII i XVIII w.), „Libri Gedanenses” 2/3: 1970, s. 88-89. 
dziejami regionu, taki zakres tematyczny jest w pełni zrozumiały. Ten zestaw uzupełniały książki z czasów szkolnych (np. gramatyki, utwory autorów starożytnych) oraz podstawowe dzieła z innych dziedzin wiedzy i stosunkowo liczna grupa książek religijnych, które były częścią składową każdej ówczesnej biblioteki prywatnej, niezależnie od wykształcenia i zainteresowań poza zawodowych jej właściciela. W każdym z tych działów znajdujemy od kilku do kilkudziesięciu poloników. Wymienionych z tytułu było około 400, co stanowi ponad jedną piątą całości, ale do tego musimy doliczyć sporą partię drobnych druków, głównie dysertacji, oracji, kazań, które wchodziły w skład nierozpisanych klocków introligatorskich. Większość poloników to płody oficyn gdańskich i toruńskiej, w mniejszym stopniu elbląskiej i cystersów w Oliwie. Poza tym posiadał sporą partię książek wydrukowanych w tłoczniach krakowskich, nieco mniej w Warszawie i Braniewie. Pojedyncze książki pochodziły z drukarni w Zamościu, Poznaniu, Wilnie, Słucku, Lesznie, Brzegu i Lwowie. Ponad $50 \mathrm{z}$ nich to teksty polskojęzyczne, co sugeruje, że ich właściciel znał język polski.

Dwa największe i najciekawsze działy tej biblioteki: prawo i polityka oraz historia, są też najbogatsze w polonika, ale nie zabrakło w nich podstawowych dzieł historycznych i z prawa powszechnego. Jako prawnik z wykształcenia, a do tego wysoki urzędnik miejski musiał Bliwernitz być dobrze zorientowany w literaturze z tego zakresu, czego potwierdzenie daje analizowany katalog aukcyjny. Burmistrz zgromadził kilka wydań prawa rzymskiego, prawa cywilnego oraz dość bogaty zestaw opracowań z zakresu różnych aspektów prawa. Tu w pierwszej kolejności znane mu były dzieła jurystów niemieckich, w tym wiele opracowań Benedykta Carpzoviusa, żyjącego w XVII w. profesora uniwersytetu w Lipsku, Caspara Manza, który z kolei wykładał w Dillingen i Ingolstadt, związanego z Jeną historyka i prawnika Burkharda Gotthelfa Struve, a także Johanna Ottona Tabora, Johanna Brunnemanna oraz Christiana Thomasiusa i Samuela Pufendorfa. Tego ostatniego, wybitnego znawcy i twórcy prawa międzynarodowego i teorii prawa natury posiadał m.in. De iure naturae et gentium z 1684 r. oraz De officio hominis et civis juxta legem naturalem w edycji gdańskiej z 1696 r. ${ }^{19}$

19 J. Serczyk, 25 wieków historii. Historycy i ich dzieła, Toruń 1994, s. 182. Edycji gdańskiej dzieła Pufendorfa nie notują ani Bibliografia polska Estreicherów, ani uzupełnienia do niej. 
Jeszcze bogatsza jest u Bliwernitza literatura prawna w zakresie problematyki polskiej. Burmistrz znał różne opracowania odnoszące się i do historii i do funkcjonowania prawa na ziemiach polskich. Szczególnie bliskie były mu teksty Gotfryda Lengnicha, gdańskiego prawnika i historyka, oraz innych jurystów związanych z tym miastem, jak na przykład Jana Nixdorffa. Znane mu było także najważniejsze dzieło Mikołaja Chwałkowskiego Ius Publicum Regni Poloniae z wydania królewieckiego z 1684 r. i dwutomowe opracowanie Mikołaja Zalaszowskiego Ius Regni Poloniae (Poznań 1701-1702). Ważną część stanowią tu wydawnictwa statutów i konstytucji sejmowych poszczególnych sejmów i zestawiające konstytucje za dłuższy okres. Z licznych prób kodyfikacji prawa do księgozbioru malborczyka trafiły m.in.: obszerne, bo liczące prawie tysiąc stron dzieło Jakuba Przyłuskiego Leges seu statuta ac privilegia Regni Poloniae (Kraków 1553), które charakteryzowało systematyczne ułożenie przepisów prawa polskiego oraz bogaty komentarz autora; zestawienie ustaw opracowane przez Jana Herburta, kasztelana sanockiego, historyka i prawnika, zatytułowane Statuta Regni Poloniae, in ordinem alphabeti digesta, cieszące się sporą popularnością ze względu na przyjęty układ, a znane Bliwernitzowi z trzeciej edycji, do której doszło w Zamościu w 1597 r.; polskojęzyczne opracowanie Jana Januszowskiego Statuta, prawa y constitucie koronne łacińskie i polskie (Kraków 1600) i Pawła Szczerbica Promptuarium statutorum omnium et constitutionum Regni Poloniae (Braniewo 1604), dzieło stanowiące streszczenie przepisów prawnych wraz z odnośnikami do odpowiednich źródeł. Tym wydawnictwom towarzyszyło jeszcze kilka zbiorowych edycji konstytucji oraz regestry i inwentarze konstytucji w opracowaniu Wojciecha Madalińskiego i Jana Dzięgielewskiego ${ }^{20}$.

Te publikacje uzupełniają druki dotyczące sytuacji prawnej miast, szlachty i całego regionu prowincji pruskiej. Prócz odnotowanych już tu w wersji rękopiśmiennej wilkierzy Gdańska, odpisów prawa chełmińskiego, a także drukowanego egzemplarza wydanego nakładem Henryka Strobanda w oficynie toruńskiej w 1584 r. pod tytułem Das alte Cölmische Recht, mamy Jura municipalia terrarum Prussiae wydane w Gdań-

20 Były to: Constitucie statuta y przywileje na walnych seymach koronnych od...1550... do... 1603 uchwalone, Kraków 1603 i Constytucje, Statuta i przywileje koronne 1650-1625, Kraków 1625; W. Madaliński, J. Dzięgielowski, Inwentarz constituciy koronnych od...1550. aż do1643 uchwalonych, Warszawa 1644. 
sku w 1578 r., a także Repertorium juris Pruthenici (Gdańsk 1730) Jana Henryka Hauensteina. Było to dzieło niezwykle przydatne mieszkańcowi i do tego wysokiemu urzędnikowi żyjącemu w jednym z miast Prus Królewskich, będące usystematyzowanym zbiorem norm prawa sądowego i publicznego, obowiązującego w prowincji pruskiej ${ }^{21}$. Tematyki regionalnej dotyczą też publikacje będące echem toczącej się w XVII w. dyskusji na temat indygenatu ${ }^{22}$.

O zainteresowaniu Bliwernitza bieżącym życiem politycznym i społecznym świadczy bogaty zbiór różnych drobnych pism, polemik, mów politycznych odnoszących się głównie do wojen z drugiej połowy XVII i początku XVIII w. Odzwierciedleniem wydarzeń dziejących się w pobliskich miastach są liczne rozporządzenia publikowane przez władze Gdańska, Torunia czy Elbląga, a gdy wydarzenie odbijało się szerszym echem poza granicami prowincji, również dokumentująca je literatura polityczna, jak np. w wypadku tzw. tumultu toruńskiego ${ }^{23}$.

Wśród książek o treści historycznej natrafiamy w bibliotece burmistrza malborskiego na prace obejmujące całościowo dzieje świata lub Europy, jak i na źródła i opracowania odnoszące się do historii poszczególnych państw europejskich, regionów czy wybranych miast. Można tu wymienić Historia sui temporis (Paryż 1604-1609 oraz w edycji późniejszej z Frankfurtu z 1659 r.), czterotomowe dzieło francuskiego historyka Jacquesa de Thou (Thuanusa), które od początku wywoływało kontrowersje i spotykało się z atakami i krytyką. Korzystając ze swych bogatych zbiorów, autor zajął się w nim okresem od $1545 \mathrm{roku}^{24}$. Przykładem pracy poświęconej dziejom jednego państwa są Annales et historiae de

${ }^{21}$ L. Pauli, Z. Zdrójkowski, Jan Henryk Hauenstein (1695?-1734) szlachcic łużycki, ławnik nowomiejski toruński, wydawca źródeł prawa chełmińskiego, „Rocznik Toruński” 18: 1988, s. 154.

22 Tu przykładem może służyć J. Werdy Indygenat ziemi pruskiey, Toruń 1645.

${ }^{23}$ Bliwernitz miał następujące druki poruszające to wydarzenie, trzy współoprawne: M. Lilienthal, Der Thornischen tragoedie 3ter Actus, Królewiec 1725; D. Schönemann, Die Dem Betrübten Thorn Aus zärtlichem Mitleyden Gewiedmete Wehmuths-volle Klage, Berlin 1726; G. Hannenberg, Authentische Nachricht Von der zu Thoren erregten- und nach Erforderung der Gerechtigkeit gestrafften Aufruhr, Stadt am Hoff 1725 oraz dwa łącznie oprawione: D. E. Jabłoński, Das Betrübte Thorn, Oder die Geschichte so sich zu Thorn Von Dem II. Jul. 1724. biß auf gegenwärtige Zeit zugetragen, Berlin 1725 i J. T. Jabłoński, Thornische Denckwürdigkeiten: worinnen die im Jahr Christi MDCCXXIV, und vorhergehenden Zeiten verunglückte Stadt Thorn, Berlin 1726.

24 J. Serczyk, dz. cyt., s. 183-184. 
rebus Belgicis (Amsterdam 1658) Hugo Grotiusa, szerszego terytorium dotyczyła zaś publikacja Alberta Krantza Regnorum aquilonarium Daniae, Sueciae, Norvagiae chronica (Frankfurt n. Menem 1583). Bliwernitzowi dobrze znana była również twórczość historyczna Samuela Pufendorfa, nie tylko prawnika, ale także urzędowego historiografa szwedzkiego, pod koniec życia historiografa brandenburskiego. Te tytuły odzwierciedlały się w tematyce jego dzieł historycznych. W omawianym księgozbiorze mamy wszystkie najważniejsze książki Pufendorfa z tego zakresu, mianowicie prace poświęcone dziejom Szwecji i Karolowi Gustawowi oraz Fryderykowi Wilhelmowi Wielkiemu. Jest też wprowadzenie do dziejów najważniejszych mocarstw i państw europejskich w edycji niemieckiej i toruńskiej ${ }^{25}$.

Przegląd poloników historycznych pokazuje, że właściciel biblioteki powinien być dobrze zorientowany w dziejach Rzeczypospolitej i Prus, dzięki dostępowi do powstałych w różnych okresach opracowań. Listę dzieł poświęconych dziejom Polski otwiera napisana w XV w. praca Jana Długosza, którą miał w najnowszej edycji, dokonanej w Lipsku w 1712 r. Następne stulecie reprezentują w księgozbiorze Bliwernitza książki takich historyków, jak: Marcin Kromer, Maciej Stryjkowski i Erazma Gliczner. Tego pierwszego posiadał główne dzieło De origine et rebus gestis Polonorum libri XXX, jednak nie z pierwszego wydania bazylejskiego z $1555 \mathrm{r}$., a opublikowane w Kolonii w 1589 r, i obejmujące też inne prace Kromera oraz dwa egzemplarze pracy Polonia, sive de situ, populis, moribus, magistratibus et republica Regni Polonici, w której pokazał Polskę mu współczesną, w autoryzowanych wydaniach u M. Cholinusa w Kolonii z lat 1577 i 1578. Do książki Kromera nawiązywały dwie inne prace w bibliotece Bliwernitza: stanowiące właściwie jego przeróbkę historyczne opracowanie z dorobku piśmienniczego Herburta Chronica sive historiae Poloniae compendiosa...descriptio (Bazylea 1571) i Polonia (Kolonia 1632)

25 Były to: Commentariorum de Rebus Suecicis: libri XXVI ab expeditione Gustavi Adolfi Regis in Germaniam ad abdicationem usque Christinae, Utrecht 1686; De Rebus a Carolo Gustavo Sueciae Rege Gestis Commentaria, Norymberga 1696; De rebus gestis Friderici Wilhelmi Magni: elektoralis Brandenburgici: commentatiorum libri novendecim, Berlin 1695; Einleitung zu der Historie der Vornehmsten Reiche und Staaten, so itziger Zeit in Europa sich befinden, Frankfurt n. Menem 1684-1710. Toruńska edycja nie jest notowana w Bibliografii polskiej Estreicherów. W katalogu aukcyjnym występuje pod tytułem: Historische Einleitung der vornehmsten Geschichte der Europäischen Könige und Potentaten, Toruń 1721. 
Szymona Starowolskiego, która była zaktualizowaną wersją De origine et rebus gestis Polonorum, publikacją mającą także cechy przewodnika. Macieja Stryjkowskiego, dziejopisarza piszącego w języku polskim, mamy również najważniejsze opracowanie, mianowicie Kronika polska, litewska, żmudzka i wszystkiej Rusi (Królewiec 1582), oraz Sarmatiae Europeae descriptio, zarys geografii i historii Polski, Litwy, Prus, Inflant, Moskwy i Tatarii do czasów Henryka Walezego. Książka ta miała kilka wydań, a ukazała się po raz pierwszy w 1581 r. w Spirze pod nazwiskiem jego zwierzchnika, Aleksandra Gwagnina. Do księgozbioru burmistrza trafił egzemplarz z nieco zmienionej edycji powstałej u Sigmunda Feyerabenda i Johanna Wechela we Frankfurcie nad Menem w 1584 r. pod tytułem Rerum Polonicarum ${ }^{26}$. Glicznera posiadał Bliwernitz opublikowane w Toruniu w 1597 r. Chronicon regum Poloniae.

Z oczywistych powodów jeszcze więcej mamy w omawianej bibliotece prac pisarzy tworzących na przełomie wieków XVI i XVII. Tu z autorów zajmujących się całością dziejów Polski należy wymienić: Salomona Neugebauera z jego dwiema książkami: Historia rerum polonicarum (Hanower 1618), do powstania której wykorzystał twórczość wcześniejszych autorów i popularne opracowanie historii Polski Icones et vitae Principum ac Regum Poloniae (Frankfurt n. Menem 1620), Krzysztofa Hartknocha, który w De Republica Polonica libri duo (Frankfurt i Lipsk 1687, drugi egzemplarz - Lipsk 1698) dał krótki rys dziejów Polski wraz z omówieniem ustroju i prawa publicznego polskiego, oraz Joachima Pastoriusa, autora między innymi Historiae Polonae plenioris partes duae (Gdańsk 1685) i bardzo popularnego podręcznika do dziejów Polski Florus Polonicus seu Polonicae historiae epitome nova, występującego w omawianym księgozbiorze aż w trzech egzemplarzach: jeden pochodził z pierwszej edycji dokonanej w Lejdzie w 1641 r., a dwa z wydania gdańskiego z 1679 r.

Uzupełniają je książki poświęcone panowaniu konkretnego władcy, jak na przykład Annales Stanisława Orzechowskiego opisujące wydarzenia z 1537 r. Praca ta po raz pierwszy drukiem ukazała się dopiero w $1611 \mathrm{r}$. za sprawą Jana Szczęsnego Herburta, ale w księgozbiorze Bliwernitza był jej egzemplarz z wydania gdańskiego z 1643 r., które ukazało się nakładem Jerzego Förstera. Okres, gdy na tronie zasiadał Henryk Walezy, omawia

${ }^{26}$ J. Serczyk, dz. cyt., s. 165; W. Budka, Gwagnin Aleksander, [w:] PSB, t. 40, Wrocław 1960-1961, s. 203. 
znajdująca się w bibliotece książka Andrzeja Maksymiliana Fredro Gestorum Populi Poloni sub Henrico Valesio (Gdańsk 1652 i egzemplarz z edycji z 1660). Twórczość tego autora reprezentowana jest jeszcze przez inne dzieła, w tym przez najpopularniejsze Monita politico-moralia et icon ingeniorum (Gdańsk 1664), stanowiące zbiór maksym odnoszących się do życia publicznego i prywatnego. Czasy po śmierci Zygmunta Augusta do 1594 r. mógł Bliwernitz poznać także z opracowania Reinholda Heindensteina, sekretarz króla Stefana Batorego, którego panowanie znane było burmistrzowi m.in. dzięki książce Jana Dymitra Solikowskiego, a o władcach z dynastii Wazów i wydarzeniach z okresu ich rządów w księgozbiorze Bliwernitza znajdujemy dla przykładu dzieło Pawła Piaseckiego pod nieco mylącym tytułem Chronica gestorum in Europa singularium (Kraków 1648), gdyż większa część dotyczy Rzeczpospolitej pod rządami Zygmunta III, panegiryczny utwór Stanisława Kobierzyckiego o księciu Władysławie Wazie, późniejszym królu, w którym autor przedstawił też okres poprzedzający wstąpienie księcia na tron. Wydarzeniom z czasów Władysława IV i temu władcy poświęcona została praca jego nadwornego historiografa, Eberharda Wassenberga, autora przy tym panegirycznego utworu o Janie Kazimierzu, a także książka Jana Innocentego Petrycego, lekarza i historiografa Akademii Krakowskiej, w której zawarł opis wydarzeń z lat 1620-1621. Wyprawę chocimską mógł poznać Bliwernitz jeszcze z diariusza Jakuba Sobieskiego, opis powstania Chmielnickiego na Ukrainie za rządów Jana Kazimierza w relacji J. Pastoriusa ${ }^{27}$. Okres po śmierci tego władcy znajdziemy omówiony w pracach Wespazjana Kochowskiego i Kazimierza Zawadzkiego, który koncentrował się przede wszystkim na panowaniu Michała Korybuta Wiśniowieckiego ${ }^{28}$.

Do księgozbioru Bliwernitza trafiły też dzieje Litwy pióra Wojciecha Wijuk Kojałowicza ${ }^{29}$ oraz liczna grupa opracowań dotyczących historii

27 R. Heindenstein, Rerum Polonicarum ab excessu Sigismundi Augusti libri XII, Frankfurt n. Menem 1672; J. D. Solikowski, Commentarius brevis rerum Polonicarum a morte Sigismundi Augusti, Gdańsk 1647; S. Kobierzycki, Historia Vladislai, Poloniae et Sueciae principis, Gdańsk 1655; E. Wassenberg, Gestorum Vladislai IV. Poloniae et Sueciae Regis, Pars 1-2, Gdańsk 1643 i tegoż, Serenissimi Johannis Casimiri Poloniarum Sveciaeque principis carcer gallicus, Gdańsk 1644; J. I. Petrycy, Rerum in Polonia ac praecipue belli cum Osmano Turcarum imperatore gesti finitique historia anno MDCXX et MDCXXI, Kraków 1637; J. Sobieski, dz. cyt.; J. Pastorius, Bellum Scythico-Cosacicum, Gdańsk 1652.

${ }^{28}$ W. Kochowski, Annalium Poloniae climacter..., Kraków 1683; K. Zawadzki, dz. cyt.

29 W. Kojałowicz, dz. cyt. 
Prus, prowincji szczególnie mu bliskiej ze względu na pochodzenie, w tym też książki poświęcone poszczególnym miastom Prus Królewskich. Tu w pierwszej kolejności należy wspomnieć XIV-wieczną kronikę Prus Piotra z Dusburga odnalezioną i przygotowaną do druku przez K. Hartknocha, do której dołączone były drobne prace tegoż autora poświęcone Prusom $^{30}$. Nie mogło zabraknąć w omawianej bibliotece najważniejszego dzieła z dorobku Hartknocha z tego zakresu, mianowicie Alt und Neues Preussen oder preussischer Historien zwey Theile (Frankfurt n. Menem 1684). Przy okazji można wspomnieć drugą istotną jego pracę, Preussische Kirchen-Historie (Frankfurt n. Menem 1686). Inną książką omawiającą historię Prus, która też przez jakiś czas pozostawała w rękopisie, było dzieło Jana Leo, duchownego katolickiego, związanego m.in. z Dobrym Miastem. Chronologicznie jego praca obejmowała dzieje Prus od czasów najdawniejszych do 1626 r., czyli po czasy współczesne kanonikowi. Jednak druku doczekała się po raz pierwszy dopiero w 1725 r. i właśnie ta edycja, dokonana w Braniewie, znana była Bliwernitzowi ${ }^{31}$. Z nowszych opracowań na uwagę zasługuje przede wszystkim historia Prus Gotfryda Lengnicha. Z tego dziewięciotomowego wydawnictwa, napisanego w języku niemieckim, w bibliotece Bliwernitza było sześć pierwszych woluminów, czyli wszystkie, które zdążyły wyjść za jego życia ${ }^{32}$. Z kolei z opracowań dotyczących miast pruskich najwięcej znajdujemy tych poświęconych Gdańskowi. Prócz wspomnianego odpisu rękopiśmiennego pracy Curicke i dwóch egzemplarzy drukowanych tej książki można tu jeszcze wymienić dzieło Bartela Ranischa Beschreibung aller Kirchen-Gebäude in der Stadt Dantzig (Gdańsk 1695), ciekawe od strony edytorskiej, bogato ilustrowane, poświęcone nie tyle historii miasta, co kościołom i ich architekturze. Historię Torunia znał Bliwernitz przede wszystkim z dzieł historyka i burmistrza Torunia Jakuba Henryka Zernecke ${ }^{33}$, Chojnic zaś

30 P. Dusburg de, Chronicon Prussiae, Frankfurt i Lipsk 1679 (w katalogu aukcyjnym, s. 15 podany jest błędny rok 1674). Por. też J. Serczyk, Hartknoch Johannes Christoph, [w:] Toruński słownik biograficzny, t. 1, pod red. K. Mikulskiego, Toruń 1998, s. 112.

${ }^{31}$ Z. Nowak, Leo Jan, [w:] PSB, t. 17, Wrocław 1972, s. 66.

32 J. Leo, Historia Prussiae, Braniewo 1725; G. Lengnich, Geschichte der preussischen Lande, Bd. 1-6, Gdańsk 1722-1729.

${ }^{33} \mathrm{~W}$ bibliotece Bliwernitza było jego główne dzieło Historiae Thoruniensis Naufrage Tabulae (Toruń 1711); praca poświęcona epidemiom w Toruniu: Das verpestete Thorn oder summarischer Auszug der Pestilenz-Seuchen (Toruń 1710) i książka o czasach wojen 
ze źródłowego wydawnictwa Izaaka Gotfryda Goedtke, mającego zacięcie historyczne burmistrza tego miasta ${ }^{34}$.

Wprawdzie nie w takim wyborze, jak w niektórych księgozbiorach mieszczan gdańskich, ale posiadał Bliwernitz także dzieła czołowych przedstawicieli renesansu, czasami te najważniejsze w ich dorobku. Najlepiej znanymi burmistrzowi malborskiemu autorami wydają się: Erazm z Rotterdamu ${ }^{35}$, Justus Lipsius z popularną Politykq ${ }^{36}$ i Hugo Grotius z De iure belli ac pacis $^{37}$. 0 zainteresowaniu się nowymi prądami świadczy jeszcze obecność w tej bibliotece czasopism. Zestaw tytułów obcych pism też był uboższy niż np. u gdańszczan, wydaje się bardziej przypadkowy i przede wszystkim nie zawsze świadczy o ich systematycznym kompletowaniu. Da się tu jednak zauważyć pewne podobieństwa: Bliwernitz był zainteresowany głównie periodykami publikowanymi w krajach niemieckich. Gromadził pisma naukowe i moralne. Jedyny tytuł, który miał w komplecie, to wychodzące od 1689 r. w Lipsku „Monathliche Unterredungen einiger guten Freunde von allerhand Büchern und andern annehmlichen Geschichten”, a od 1704 do 1706 we Frankfurcie n. Menem i Lipsku pod zmienionym tytułem „Curieuse Bibliothek, oder Forts. der Monatlichen Unterredungen”. Co ciekawe, wydawcą pierwszego numeru tego czasopisma, obok lipskiego drukarza Johanna Friedricha Gleditscha, był działający w Toruniu księgarz i nakładca Jan Chrystian Laurer ${ }^{38}$. Przez pewien czas był jeszcze zainteresowany „Neuer Büchersaal der Gelehrten Welt", innym periodykiem ogólnonaukowym publikowanym w Lipsku w latach 1710-1717, u Bliwernitza dostępne było pierwszych pięć roczników. Był też stałym czytelnikiem „Erläutertes Preussen”, czasopisma historycznego z lat 1723-1728, z którym współpracował, choć

szwedzkich: Das bei denen schwedischen Kriegen bekriegte Thorn... was sich bei dieser Stadt im Jahr 1629, 1655, 1658 und 1703...zugetragen, Toruń 1712.

34 I. G. Goedtke, Geschichte der Stadt Coenitz, Gdańsk 1724.

35 Z prac Erazma z Rotterdamu można wymienić: Adagia Chiliades iuxta locos communes digestae, Hanower 1617; Familiarium colloquiorum opus, Lyon 1581 i Opera, Bazylea 1536.

${ }^{36}$ Dzieło to w omawianej bibliotece występuje w dwóch edycjach: Strasburg 1641 i Frankfurt n. Menem 1653.

37 Tej pracy miał tez dwa egzemplarze: oba wydane w Amsterdamie w 1651 i $1680 \mathrm{r}$.

38 J. Kirchner, Die Grundlagen des deutschen Zeitschriftenwesens mit einer Gesamtbibliographie der deutschen Zeitschriften bis zum Jahre 1790, Tl. 2, Leipzig 1931, s. 3, poz. 33 i 6, poz. 67. 
w bibliotece nie znajdujemy rocznika z jego tekstami. Miał tylko jeden tom hamburskiego „Nova Litteraria Germaniae” (pierwszy rocznik z 1703 r.). Czasopisma moralne reprezentował w jego kolekcji bardzo popularny hamburski „Der Patriot” (1724-1726), którego miał komplet. Bliwernitz był zainteresowany także pierwszymi czasopismami na ziemiach polskich, publikowanymi w Gdańsku i Toruniu na początku XVIII w. W tym wypadku miał wszystkie wychodzące za jego życia tytuły, począwszy od dziesięciu numerów „Polnische Bibliothec”, pisma poświęconego historii Polski, redagowanego w Gdańsku w latach 1718-1719 przez G. Lengnicha, po toruńskie periodyki drukowane w latach 20.: „Das Gelahrte Preusse”, którego miał 3 tomy, komplet „Preussischer Todes Tempel”, których redaktorem był Jerzy Piotr Schultz oraz pierwszy tom „Meletemata Thorunensia" Piotra Jaenichena.

Nie mogło zabraknąć w omawianej bibliotece literatury religijnej, w przypadku Bliwernitza protestanckiej, głównie luterańskiej. Prace innych odłamów protestantyzmu czy katolików reprezentowane są jedynie przez pojedyncze tytuły. Jak w każdym księgozbiorze z tamtych czasów wyznawcy religii luterańskiej, burmistrz posiadał kilka egzemplarzy Biblii, w całości lub we fragmentach. Miał edycje starsze, XVI-wieczne, jak Biblia vulgata latina, egzemplarz pochodzący z Lyonu z 1549 r., jak i wydania nowe, z początku XVIII stulecia, np. dwutomowa Biblia pentapla: Das ist die Bücher der Heiligen Schrift des Alten und Neuen Testaments nach Fünf-facher Deutscher Verdolmetschung (Hamburg 1711-1712). W księgozbiorze natrafiamy tylko na protestanckie edycje Biblii, głównie po łacinie lub po niemiecku, ale jest jeden przekład francuskojęzyczny i dwa wydania w języku polskim: amsterdamskie z 1660 r. i drukowane w Halle w 1726 r. W obu przypadkach podstawą edycji była tzw. Biblia gdańska, opublikowana w Gdańsku w 1632 r. przez Andrzeja Hünefelda. Mamy tu jeszcze Jana Kochanowskiego przekład Psałterza Dawidów ${ }^{39}$. Ta grupa książek, po pracach z zakresu prawa i polityki, jest w księgozbiorze Bliwernitza najbogatsza w publikacje w języku polskim. Niemieckojęzycznym katechizmom, kancjonałom, kazaniom i innym rozważaniom autorstwa głównie duchownych z Prus Królewskich towarzyszyły śpiew-

${ }^{39}$ W katalogu odnotowane zostały dwa egzemplarze Psałterza z dwóch różnych edycji: jedna krakowska z 1606 r. w czwórce, druga w formacie dwójki, ale bez podania miejsca i roku druku. 
niki, rozważania i zbiory modlitw polskojęzyczne, drukowane w drugiej połowie XVII w. przede wszystkim w tłoczni toruńskiej, co kolejny raz potwierdza, że Toruń w tym czasie był ważnym ośrodkiem książki polskiej. Jest jeszcze jeden powód sporej liczby druków toruńskich w księgozbiorze burmistrza, mianowicie jego pochodzenie i związki rodzinne z Aaronem Bliwernitzem, nie tylko pastorem, ale też nauczycielem języka polskiego i autorem wielu tekstów i przekładów, w tym Rozmyślania nabożne i Lekarstwo duszne Jana Gerharda, obie prace drukowane w Toruniu w latach 1682 i 1684. Jego autorstwa miał zaś drukowany w Gdańsku w 1683 r. Brewiarz nabożeństwa chrześcijańskiego, to jest: Modlitwy nabożne każdemu czasowi y potrzebom pospolitym służące, z Pisma S. nabożnych nauczycielów kościelnych zebrane, który z założenia był drugą częścią Rozmyślań nabożnych i tak też został potraktowany przez właściciela omawianej biblioteki.

Bogato reprezentowana była jeszcze literatura antyczna, co należy łączyć z ówczesnym programem nauczania zarówno na poziomie średnim, jak i uniwersyteckim. Pozostałość po czasach szkolnych może jeszcze stanowić kilka gramatyk języka łacińskiego, słowników i rozmówek pomocnych do nauki języka polskiego. W tym wypadku Bliwernitzowi znane były przede wszystkim wydawnictwa regionalnych autorów, jak cieszące się dużą popularnością od końca XVI w. rozmówki Mikołaja Volckmara, rozmówki wraz z przysłowiami polskimi i gramatyką języka polskiego autorstwa Jana Karola Woyny czy podręcznik języka polskiego pióra Jana Monety ${ }^{40}$. Korzystał też ze słownika łacińsko-niemiecko-polskiego powstałego na bazie słownika łacińsko-niemieckiego Dasypodiusza i oczywiście ze słowników Grzegorza Knapskiego ${ }^{41}$.

\section{Podsumowanie}

Przedstawione powyżej główne działy z księgozbioru Bliwernitza i przykładowe tytuły posiadanych przez niego książek nie wyczerpują ca-

${ }^{40}$ M. Volckmar, Vierzig Dialogi, oder lustige Arten zu reden, Gdańsk 1660; J. K. Woyna, Kleiner Lustgarten, worin gerade Gänge zur polnischen Sprache angewiesen werden, Gdańsk 1712 i J. Moneta, Enchiridion Polonicum oder polnisches Handbuch, Gdańsk 1720.

41 P. Dasypodius, Dasypodius catholicus, hoc est dictionarium latino-germanicopolonicum, germanico-latinum et polono-latino-germanicum, Gdańsk 1642; G. Knapski, 
łego bogactwa tej biblioteki. W jego zbiorach nie zabrakło wydawnictw o charakterze encyklopedycznym, jak popularna w XVII w. Encyclopaedia (Herborn 1630) Johanna Heinricha Alsteda, czy też literatury pięknej, na przykład utworów Macieja Kazimierza Sarbiewskiego, poematu biblijnego Stanisława Herakliusza Lubomirskiego zatytułowanego Tobiasz wyzwolony, czy wreszcie szwedzkiej i hiszpańskiej wersji Robinsona Crusoe. W sumie zdołał burmistrz skompletować spory i ciekawy zbiór, wyraźnie odzwierciedlający jego potrzeby zawodowe i zainteresowania historyczne, a przy tym wskazujący, że był otwarty na płynące z Zachodu nowe prądy umysłowe. Nie wykluczało to oczywiście zainteresowania tradycyjną literaturą. Można powiedzieć, że analizowany księgozbiór niewiele odbiegał od charakteru bibliotek prywatnych gromadzonych na przełomie stuleci XVII i XVIII przez urzędników miejskich Gdańska, Torunia i Elbląga, choć burmistrz miał zdecydowanie mniejsze możliwości zakupu książek na miejscu. Niewykluczone, że korzystał z pomocy księgarzy gdańskich i toruńskich, w czym mogły mu pomagać katalogi księgarskie wykazane też w katalogu aukcyjnym ${ }^{42}$. Pod względem „nasycenia” księgozbioru w druki tematycznie związane ze sprawami lokalnymi, prowincji czy Rzeczypospolitej oraz publikacji, które wyszły spod pras działających w pobliżu Malborka tłoczni i książek w języku polskim, biblioteka Bliwernitza trochę odbiegała od kolekcji wysokich urzędników gdańskich, a bliżej jej było do burmistrzów czy rajców toruńskich i elbląskich.

\section{The library of Jakub Bliwernitz (1667-1731), the mayor of Malbork}

ABSTRACT: Living at the turn of the seventeenth and eighteenth centuries, James Bliwernitz was among the well-educated elite of Malbork. He was appointed the mayor of the city several times. He studied law and was interested in the history of the region. He is also known as the owner of a sizeable book collection of about

Thesaurus polonolatonograecus seu promptuarium linguae latinae et graecae, Kraków 1643 i tegoż Synonima seu dictionarium polono-latinum, Poznań 1715.

${ }^{42}$ Niestety katalogi księgarskie i biblioteczne jako druki drobne zostały potraktowane przez autora katalogu aukcyjnego sumarycznie, pod tytułami: Fasciculus Catalogorum Libror. i Fasciculus Catalogorum Bibliothecar. 
2,000 items. After his death the collection was sold at a public auction held in Malbork on 16 July 1732. A printed auction catalog presents the contents of his library, with its character and size not very different from other private libraries of the time owned by city officials of the major provincial cities such as Torun and Elblag. The Bliwernitz collection was dominated by books on law, politics and history, supplemented with religious literature, handbooks and basic works in other fields. The mayor used the books primarily to carry out his professional duties as well as to implement his historical interests.

KEYwordS: Bliwernitz Jakub (1667-1731), historical collections, Malbork, private libraries, $17^{\text {th }}$ century, $18^{\text {th }}$ century. 